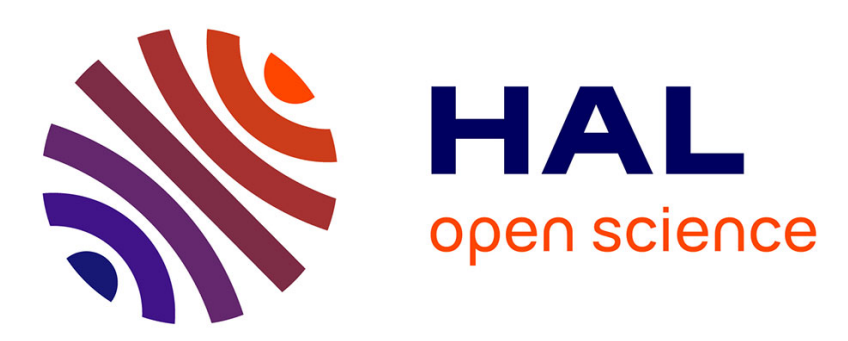

\title{
Yield and composition of pectin extracted from Tunisian pomegranate peel
}

\author{
Mouna Abid, Catherine M.G.C. Renard, Aude Watrelot, Imen Fendri,
} Hamadi Attia, Med Ali Ayadi

\section{- To cite this version:}

Mouna Abid, Catherine M.G.C. Renard, Aude Watrelot, Imen Fendri, Hamadi Attia, et al.. Yield and composition of pectin extracted from Tunisian pomegranate peel. International Journal of Biological Macromolecules, 2016, 93, pp.186-194. 10.1016/j.ijbiomac.2016.08.033 . hal-02635045

\section{HAL Id: hal-02635045 \\ https://hal.inrae.fr/hal-02635045}

Submitted on 27 May 2020

HAL is a multi-disciplinary open access archive for the deposit and dissemination of scientific research documents, whether they are published or not. The documents may come from teaching and research institutions in France or abroad, or from public or private research centers.
L'archive ouverte pluridisciplinaire HAL, est destinée au dépôt et à la diffusion de documents scientifiques de niveau recherche, publiés ou non, émanant des établissements d'enseignement et de recherche français ou étrangers, des laboratoires publics ou privés. 


\title{
Yield and composition of pectin extracted from Tunisian pomegranate peel
}

\author{
Mouna Abid ${ }^{\mathrm{a}}$, Catherine M.G.C. Renard ${ }^{\mathrm{b}, \mathrm{c}}$, Aude A. Watrelot ${ }^{\mathrm{b}}$, Imen Fendri ${ }^{\mathrm{d}}$, \\ Hamadi Attia ${ }^{a}$, M.A. Ayadi ${ }^{\mathrm{a}, *}$ \\ a Laboratoire Analyse, Valorisation et Sécurité des Aliments, Université de Sfax, Ecole Nationale d'Ingénieurs de Sfax (ENIS), BP 3038, Sfax, Tunisia \\ b INRA, UMR408 Sécurité et Qualité des Produits d'Origine Végétale, F-84000, Avignon, France \\ ' Université d'Avignon, UMR408 Sécurité et Qualité des Produits d'Origine Végétale, F-84000, Avignon, France \\ d Unité de recherche Toxicologie - Microbiologie environnementale et santé, Faculté des Sciences de Sfax, Tunisia
}

Keywords:

Punica granatum L

Response surface methodology

Extraction

Pectin

\begin{abstract}
A B S T R A C T
A central composite design was employed to determine the influence of extraction conditions on production yield and chemical composition of pectin from pomegranate peels. Response surface methodology (RSM) was used to quantify the integral effect of the three processing parameters (extraction duration, temperature and $\mathrm{pH}$ ) on yield. A second-order polynomial model was developed for predicting the yield of pomegranate peels pectin based on the composite design. Yields ranged from 6.4 to $11.0 \pm 0.2 \%$. Optimal temperature, duration and $\mathrm{pH}$ value of the extraction were $86^{\circ} \mathrm{C}, 80 \mathrm{~min}$ and 1.7 , respectively. The uronic acid and the total neutral sugar content of the extracted pectins ranged from 377 to $755 \mathrm{mg} / \mathrm{g}$ and from 161 to $326 \mathrm{mg} / \mathrm{g}$, respectively. Moreover, the degree of methylation varied with the extraction conditions and the extracted pectins were low methylated. On high pressure size exclusion chromatography (HPSEC), the elution pattern of the acid-extracted pectins showed that severe conditions were associated with lower hydrodynamic volume.
\end{abstract}

\section{Introduction}

Pectin is a high value functional food ingredient because of its excellent gelling properties and is commonly used in food industry as gelling agent and stabilizer (E440) [1]. It belongs to the group of polysaccharides from higher plants and has several positive effects on human health, including lowering cholesterol and serum glucose levels, reducing cancer and stimulating the immune response [2].

Commercial pectin is essentially extracted from by-products of juice manufacturing, including citrus peels and apple pomace [1]. Many other agricultural by-products such as banana peels [3], sunflower heads [4] and peach pomace [5] were tested for pectin extraction. However, only little attention has so far been paid to

Abbreviations: RSM, response surface methodology; HPSEC, high pressure size exclusion chromatography; DM, degree of methylation; CCRD, central composite rotational design; MS, mass spectrometry; Gal A, galacturonic acid; ET, elution time; Rha, rhamnose; LM, low methoxyl; HM, high methoxyl; AIS, alcohol insoluble solids; $\mathrm{HNO}_{3}$, nitric acid; Fuc, fucose; Ara, arabinose; Xyl, xylose; Man, mannose; Gal, galactose; Glc, glucose; TNS, total neutral sugars.

* Corresponding author.

E-mail addresses: ayadimedali@yahoo.fr, ayadimedali@gmail.com (M.A. Ayadi). the study of pectin from pomegranate peel which is a potential and inexpensive candidate [6,7]. Pomegranate pectins appear to have lower degrees of methylation than classical (apple or citrus) sources [6]; however their molar mass distribution and the proportion of neutral side chains, that also impact functionality, has not been reported.

Pomegranate (Punica granatum L.) belongs to the Punicacea family. The cultivation of pomegranate is native to the Middle East and was later known in the Mediterranean. In Tunisia, pomegranate trees have been cultivated since ancient times. The cultivation occupies more than 11.000 ha and extends on all areas, except high level areas. More than 60 local varieties have been denominated (Jbeli, Tounsi, Zehri, Mekki, etc.).

Pomegranate is popularly consumed as fresh fruit or food products (juice, jams and jellies) and is considered as a very interesting fruit "according" to its potential health benefits.

Currently, increases in the production and processing of pomegranate have generated increasing waste, resulting in million tons of pomegranate peel being disposed of every year. In Tunisia and other pomegranate-producing countries, processing this pomegranate waste which constitutes approximately $40 \%$ of the whole fruit [8], could provide economic advantages and decrease some of the environmental problems. Because 
Version définitive du manuscrit publiée dans / Final version of the manuscript published in :

International Journal of Biological Macromolecules (2016), Vol. 93, p. 186-194,

DOI: 10.1016/j.ijbiomac.2016.08.033 - Journal homepage : www.elsevier.com/locate/ijbiomac

pomegranate peels are readily available, they could be used to recover value-added compounds such as pectins. It was reported that the efficacity of pectin extraction is affected by different factors, mainly temperature, duration and $\mathrm{pH}$ [9]. Response surface methodology (RSM) was proved to be an effective statistical technique for investigating individual and combined effects of processing variables and optimizing the extraction process.

In this context, the main objectives of this work were firstly to optimize, via RSM, pectin extraction with nitric acid from pomegranate peel of 'Gabsi' which is the most consumed variety in Tunisia, and secondly to study the composition of the extracted pectins. The optimal conditions were determined for maximum extraction of pectin, thereby enabling the use of pomegranate peel as a source of low methoxyl pectin for the production of low-calorie and dietetic foods, particularly pomegranate-based-food.

\section{Materials and methods}

\subsection{Plant material}

Pomegranate fruits from the "Gabsi" cultivar were collected from an oasis at Gabes region (southeast of Tunisia). Fruits were manually peeled then the collected peels were cut into small pieces, oven dried at $50^{\circ} \mathrm{C}$ (WTB binder-78532 TUTTLINGEN, Germany) and ground (particles' size between $0.5 \mathrm{~mm}$ and $1.25 \mathrm{~mm}$ ) to conduct pectin's extraction described in Section 2.2.

\subsection{Pectin extraction}

A total of $2 \mathrm{~g}$ pomegranate peel was stirred at $400 \mathrm{rpm}$ (Stirrer Heidolph RZR 20051 electronic, Germany) in $100 \mathrm{~mL}$ of the $\mathrm{HNO}_{3}$ solution (solid-liquid ratio; $1: 50 ; \mathrm{g} / \mathrm{mL}$ ) using the extraction conditions established by the experimental designs.

The resulting slurries were allowed to cool to room temperature $\left(25^{\circ} \mathrm{C}\right)$ and filtered through cheesecloth. For pectin precipitation, two volumes of $96 \% \mathrm{w} / \mathrm{w}$ ethanol were added to the filtrate. The obtained mixture was kept for $1 \mathrm{~h}$ at $4{ }^{\circ} \mathrm{C}$. Then, pectin gels were centrifuged at $8000 \mathrm{~g}$ for $20 \mathrm{~min}$ at $10^{\circ} \mathrm{C}$. To remove the mono and disaccharides, the pectin precipitate was washed with $50 \%, 75 \%$ and two times with $100 \%$ ethanol and centrifuged at $5000 \mathrm{~g}$ for $10 \mathrm{~min}$ at $10^{\circ} \mathrm{C}$. Finally, the obtained pectin was oven dried at $45^{\circ} \mathrm{C}$ to a constant weight, and ground in a mortar.

The gravimetric yield was estimated as the ratio between the weight of the powdered pectin and the weight of the flour raw material $(\%, g / g)$, both on a dry basis. The experiments to determine the effect of extraction duration, temperature and acid concentration followed the experimental design described as follows.

\subsection{Experimental design}

A response surface methodology (five levels, three variable central composite rotational design [CCRD]) was used to optimize pectin extraction. The design comprised eight points of a factorial design, six axial points at a distance $\alpha= \pm 1.68$ from the centre, and a centre point. In order to estimate pure error variance, six replications were performed at the centre point. The number of experiment required is given by the expression $2^{\mathrm{k}}\left(2^{3}=8\right.$ points $)+2 \times \mathrm{k}(2 \times 3=6$ axial points $)+6$ centre points ( 6 replications) [10].

The ranges and the central point values of the three independent variables were based on the results of a preliminary study. The independent factors studied were extraction duration (5 min-125 min), temperature $\left(65.2-98.8^{\circ} \mathrm{C}\right.$ ) and nitric acid concentration $(6-100 \mathrm{mmol} / \mathrm{L})$. The variables and their levels, with both the coded values and the real values used in this study, are
Experimental domain of the central orthogonal composite design used for pectin extraction from pomegranate peel.

\begin{tabular}{|c|c|c|c|c|c|}
\hline \multicolumn{6}{|l|}{ Coded levels } \\
\hline \multirow[b]{2}{*}{ Factor } & -1.68 & -1 & 0 & +1 & +1.68 \\
\hline & \multicolumn{5}{|c|}{ Experimental levels } \\
\hline $\mathrm{X} 1$ : Extraction duration (min) & 5 & 29 & 65 & 100 & 125 \\
\hline $\mathrm{X} 2$ : Temperature $\left({ }^{\circ} \mathrm{C}\right)$ & 65.2 & 72 & 82 & 92 & 98.8 \\
\hline X3: Nitric acid concentration $(\mathrm{mmol} / \mathrm{L})$ & 6 & 11 & 25 & 58 & 100 \\
\hline Equivalent $\mathrm{pH}$ & 2.2 & 1.96 & 1.6 & 1.24 & 1 \\
\hline
\end{tabular}

shown in Table 1 . The experiments were performed randomly to avoid systematic errors.

A regression analysis was done to fit the tendency to second order polynomial model as shown in Eq. (1).

$$
\begin{aligned}
y & =b_{0}+b_{1} X_{1}+b_{11} X_{1}^{2}+b_{2} X_{2}+b_{22} X_{2}^{2}+b_{3} X_{3}+b_{33} X_{3}^{2}+b_{12} X_{1} X_{2} \\
& +b_{13} X_{1} X_{3}+b_{23} X_{2} X_{3}
\end{aligned}
$$

where $\mathrm{y}$ is the response variable, $\mathrm{b}_{0}, \mathrm{~b}_{1}, \mathrm{~b}_{2}$ and $\mathrm{b}_{3}$ are the regression coefficients of variables for individual effects, $b_{11}, b_{22}$ and $b_{33}$ are quadratic effects and $b_{12}, b_{13}$ and $b_{23}$ are interactive effects. $X_{1}, X_{2}$ and $\mathrm{X}_{3}$ are independent variables.

The obtained response values were used to estimate the model coefficients bj by the least square method using the experimental design software NEMROD-W [11].

\subsection{Pectin characterization}

Neutral sugars were measured as alditol acetates after hydrolysis in $1 \mathrm{~mL}$ of $1 \mathrm{~mol} / \mathrm{L}$ sulfuric acid $\left(3 \mathrm{~h}, 100^{\circ} \mathrm{C}\right)$ with inositol as an internal standard. After hydrolysis, they were derivatized to alditol acetates [12]. They were injected on a gas chromatography-flame ionization detector HP5890 Series II (Agilent, Inc.,PaloAlto, CA) with a capillary column of $30 \mathrm{~m} \times 0.25 \mathrm{~mm}$ i.d. coated with DB225 mass spectrometry (MS), having a $0.25 \mathrm{~mm}$ film thickness (J\&W Scientific, Agilent, Inc.). The conditions for injection were as follows: hydrogen was the carrier gas at $45 \mathrm{~cm} / \mathrm{s}$ (at $215^{\circ} \mathrm{C}$ ); the column flow was $1.3 \mathrm{~mL} / \mathrm{min}$; the temperature was $250^{\circ} \mathrm{C}$ in split mode (ratio 1:25); and the oven temperature was isothermal at $215^{\circ} \mathrm{C}$.

The galacturonic acid content (GalA) was determined by a meta-hydroxyl-diphenyl assay according to Blumenkrantz and Asboe-Hansen [13]. The methanol concentration (MeOH) was determined according to Renard and Ginies [14] by HeadspaceGC-MS after saponification. Samples $(10 \mathrm{mg})$ were dissolved or suspended in $3.8 \mathrm{~mL}$ of distilled water and then saponified by the addition of $0.8 \mathrm{~mL}$ of $1 \mathrm{~mol} / \mathrm{L} \mathrm{KOH}$ containing $\mathrm{CD}_{3} \mathrm{OH}(1.4 \mu \mathrm{mol} / \mathrm{mL})$ as an internal standard, and incubated for $2 \mathrm{~h}$ at room temperature. For GC, a Shimadzu QP2010 GC-MS was used with a Cp-wax$52 \mathrm{cb} 30 \mathrm{~m} \times 0.32 \mathrm{~mm} \times 0.5 \mu \mathrm{m}$ capillary column (Varian, Inc., Palo Alto, USA) equipped with an AOC5000 auto sampler. A sealed vial was placed at $50^{\circ} \mathrm{C}$ for $15 \mathrm{~min}$ and then $0.5 \mathrm{~mL}$ of head-space was injected into the split injector (1:10 ratio). The GC conditions were as follows: helium as gas carrier at $45 \mathrm{~cm} / \mathrm{s}$ and oven temperature at $40^{\circ} \mathrm{C}$ (isothermal). The mass detector conditions were: electronic impact ionization mode $(70 \mathrm{eV})$, temperature of source $200^{\circ} \mathrm{C}$ with data collected using SIM for selected ions $(\mathrm{m} / z 31 ; 32 ; 35)$ at 5 scans/s. The degree of methylation (DM) was calculated as the molar ratio of methanol to galacturonic acid.

The hydrodynamic volume distribution of polysaccharides was determined using a high pressure size exclusion chromatography (HPSEC) system comprising a Jasco LC-NET II/ADC interface, a Jasco PU-2080 plus intelligent HPLC pump, a Jasco RI-2031 plus intelligent RI detector, and a degasser, and was controlled by ChromNav solftware (Jasco,Tokyo, Japan). Separations were achieved using two columns in series: a $8.0 \mathrm{~mm} \times 300 \mathrm{mmi}$.d. $\mathrm{OH}-$ 
Version définitive du manuscrit publiée dans / Final version of the manuscript published in :

International Journal of Biological Macromolecules (2016), Vol. 93, p. 186-194,

DOI: 10.1016/j.ijbiomac.2016.08.033 - Journal homepage : www.elsevier.com/locate/ijbiomac

pack SB-802 HQ column (Showa Denko Europe, Munich, Germany) and a $300 \times 7.8 \mathrm{~mm}$ i.d. TSK-Gel PWXL column (Tosohaas, Stuttgart, Germany) at $35^{\circ} \mathrm{C}$ and a $40 \times 6.0 \mathrm{~mm}$ i.d. guard column TSK-Gel PWXL (Tosohaas, Stuttgart, Germany). Solutions $(20 \mu \mathrm{L})$ of the extracts $(5 \mathrm{~g} / \mathrm{L})$ were injected and eluted with $0.4 \mathrm{~mol} / \mathrm{Lsodium}$ acetate buffer $\mathrm{pH} 3.5$ at $0.8 \mathrm{~mL} / \mathrm{min}$. Dextrans $\mathrm{T} 500$ and $\mathrm{T} 40$ (Pharmacia BioProcess Technology, Uppsala, Sweden) and glucose (Sigma-Aldrich, Deisenhofen, Germany) were used tocalibrate the column system. All data are presented as a function of elution time of the samples (ET).

\subsection{Statistical analysis}

Analysis of pectin samples was performed in duplicate, and pooled standard deviations were calculated for each series of duplicates using the sum of individual variances pondered by the individual degrees of freedom [15]. Statistical analysis was performed using the Statistical Package for the Social Sciences "SPSS" (version17). Duncan test was performed to evaluate the significance of differences between mean values at the level of $\mathrm{P}<0.05$.

The statistical analysis of the dependent variables in the experimental design were carried out using the experimental design software NEMROD-W [11]. Lack of fit, error and model significance were used to judge the adequacy of each model. The fitted model is considered adequate if the variance due to the lack of fit is not significantly different (F-test at the 95\% level) from the pure error variance. After obtaining the multifactorial ANOVA, contour plots of the responses "yield" and "galacturonic acid content" were generated.

\section{Results and discussion}

\subsection{Extraction yield}

Fifteen experiments were carried out according to the conditions indicated in Table 1. Pectin yields are reported in Table 2 . The acid-extracted pectin yield ranged from 6.4 to $11.0 \pm 0.2 \%$ of the dry weight of the peel with the highest yield obtained at $82^{\circ} \mathrm{C}, \mathrm{pH}$ 1.6 for $65 \mathrm{~min}$. The yields (64-112 $\mathrm{mg} / \mathrm{g}$ pomegranate peel) compare favorably with those obtained by Peireira et al. [6] using citric acid and the alcohol insoluble solids (AIS) from pomegranate peel (39-110 mg/g), specially given that AIS represented less than $50 \%$ of the pomegranate peel powder in their experiment. Moorthy et al. [7] obtained higher yields using ultrasound assisted extraction and lower pH (the acid used was not specified). Kar and Arslan [16] reported that the extraction process as well as the fruit variety and maturity can affect the quantity and quality of extracted pectin.

The relationship between the extraction yield and the three selected quantitative variables was approximated by the following second order polynomial function (Eq. (2)):

$$
\begin{gathered}
\text { Yield }=109.817+5.825 X_{1}+4.322 X_{2}-1.794 X_{3}-11.468 X_{1}^{2} \\
-7.363 X_{2}^{2}-9.68 X_{3}^{2}-2.594 X_{1} X_{2}-5.606 X_{1} X_{3}-3.894 X_{2} X_{3}
\end{gathered}
$$

Coefficient values and statistical parameters obtained for the model are given in Table 3. The results obtained are then analysed by F-statistical test for analysis of variance (ANOVA) to assess the "goodness of fit". The variance analysis (Table 3) showed significant interactive effect between quantitative variables on the pectin yield. The individual effects of temperature and extraction duration were the most influential parameters.

The result of the ANOVA analysis for the model is shown in Table 4 . The fitted model is found to be significant at 95\% confidence level by the F-test and the lack of fit is not significant (data not shown). The coefficient of determination, $\mathrm{R}^{2}$, for pectin extraction yield was 0.978 .

\subsubsection{Interaction effects of extraction duration and temperature on pectin extraction rate}

Both extraction duration and temperature displayed significantly quadratic effects on the yield of pectin (Table 3 ). As shown in the response surface and contour plots (Fig. 1A), extraction of pectin was affected by changing temperature (from $65.2^{\circ} \mathrm{C}$ to $98.8^{\circ} \mathrm{C}$ ) and duration (from $5 \mathrm{~min}$ to $125 \mathrm{~min}$ ). The extraction yield of pectin first increased rapidly with the increase of both extraction duration and temperature, until $91.3 \mathrm{~min}(+0.75)$ and $89.5^{\circ} \mathrm{C}(+0.75)$. The total yield of pectin was significantly less at lower temperature and shorter duration. The reason was that the pectin was less dissolved out from the plant cell wall if the extraction temperature was too low and extraction duration was too short. Besides, much higher extraction temperature (above $90^{\circ} \mathrm{C}$ ) and too long extraction duration (above $91 \mathrm{~min}$ ) may cause breakdown of pectin molecules as already observed by Chang et al. [17].

\subsubsection{Interaction effects of extraction $\mathrm{pH}$ and temperature on pectin extraction rate}

It is apparent from the isoresponse contours that $\mathrm{pH}$ played a great role in the extraction of pectin from pomegranate peel. As shown in Fig. 1B, maximum pectin yield was obtained by soaking the peels in a solution of $\mathrm{pH} 1.5(+0.25)$ to $1.85(-0.75)$. However, decline in pectin yield was observed at $\mathrm{pH}<1.5$ for all temperatures.

The examination of the combined effects of temperature and $\mathrm{pH}$ showed that the yield increased when increasing temperature and/or decreasing the $\mathrm{pH}$, down to the limit of $\mathrm{pH} 1.5$. These effects were marked for temperatures $<92{ }^{\circ} \mathrm{C}(+1)$ and low pH levels $(2.2$ until 1.5). This can be explained by the cleavage of linkages between pectins and other cell wall components, giving a higher yield of extraction [18].

With regard to the effect of $\mathrm{pH}$, El-Nawawi and Shehata [19] reported that acidic conditions contribute to hydrolyze the insoluble pectic constituents into soluble pectin, which increases the pectin recovery. Mayers and Baker [20] reported that yield of pectin increased with decrease in the $\mathrm{pH}$ of the extractant and maximum yield of pectin was obtained from lemon albedo with hydrochloric at pH of 1.45. On the other hand, Kim et al. [21] found that temperature was the main parameter influencing the pectin recovery from mandarin. Chen et al. [22] reported that temperature increases the ability of the solvent to solubilize the compounds and reduce the viscosity of the liquid solvent, allowing for better penetration of the solvent into the solid matrix.

\subsubsection{Interaction effects of extraction $\mathrm{pH}$ and extraction duration on pectin extraction rate}

The effect of duration and $\mathrm{pH}$ was given in Fig. 1C. Once again, the isoresponse curves showed that a long duration and a low $\mathrm{pH}$ of extraction led to higher yields. At $82^{\circ} \mathrm{C}$, the maximum yields (10.8\%) were reached at a $\mathrm{pH}$ in the range of $1.5-1.85$ and extraction duration between 56 and $91 \mathrm{~min}$. A study on pectin extraction from dried okra pod powder has shown that at a fixed temperature of $60^{\circ} \mathrm{C}$ and at low $\mathrm{pH}$, the pectin yield improved with increasing extraction duration but decreased after $64 \mathrm{~min}$ [22].

\subsection{General composition of the extracted pectin}

Different conditions of extraction on the same raw material were used, so that the effects of extraction conditions on the composition of pectin could be studied. The average galacturonic acid content (GalA), the total neutral sugars (TNS), the galacturonic acid to rhamnose (GalA/Rha) molar ratio composition, the degree of 
Version définitive du manuscrit publiée dans / Final version of the manuscript published in :

International Journal of Biological Macromolecules (2016), Vol. 93, p. 1.86-194,

DOI: 10.1016/j.ijbiomac.2016.08.033 - Journal homepage : www.elsevier.com/locate/ijbiomac

Table 3

Coded regression coefficients and statistical parameters obtained for the model built for pectin yield from pomegranate peel.

\begin{tabular}{lllll}
\hline Coefficient & Coefficient value & Standard deviation & $\mathrm{T}$ & P-value \\
\hline b0 & 109.817 & 1.305 & 84.18 & $<0.01^{* * *}$ \\
b1 & 5.825 & 0.866 & 6.73 & $<0.01^{* * *}$ \\
b2 & 4.322 & 0.865 & 4.99 & $0.0543^{* * *}$ \\
b3 & -1.794 & 0.865 & -2.07 & 6.5 \\
b11 & -11.468 & 0.843 & -13.61 & $<0.01^{* * *}$ \\
b22 & -7.363 & 0.842 & -8.74 & $<0.01^{* * *}$ \\
b33 & -9.686 & 0.842 & -11.5 & $<0.01^{* * *}$ \\
b12 & -2.594 & 1.131 & -2.29 & $4.47^{*}$ \\
b13 & -5.606 & 1.131 & -4.96 & $0.0572^{* * *}$ \\
b23 & -3.894 & 1.131 & -3.44 & $0.630^{* *}$ \\
\hline
\end{tabular}

b0, bj, bjk and bjj, the estimated model coefficients; degree of freedom $=10$.

Significant at the level 95\%.

** Significant at the level $99 \%$.

*** Significant at the level $99.9 \%$.

methylation (DM) and the elution time (ET) of the main HPSEC peak of pectin samples are listed in Table 2 .

\subsubsection{Galacturonic acid content}

The average content of galacturonic acid was $529 \mathrm{mg} / \mathrm{g}$. The galacturonic acid content varied from 377 to $755 \mathrm{mg} / \mathrm{g}$ (Table 2). The highest values $(755 \mathrm{mg} / \mathrm{g})$ were obtained when pectin was extracted at the lowest $\mathrm{pH}(+1.68)(\mathrm{A} 14)$ or at the extreme conditions (A8). Extreme extraction conditions led to better extraction of pectin with higher purity probably by release of neutral sugar side chains as a product of partial acid hydrolysis of pectin [23]. Indeed, the content in both total neutral sugar and arabinose decrease particularly in this sample A8 (161 mg/g and $2 \mathrm{mg} / \mathrm{g}$; respectively). The composition data was also analysed following the experimental design paramters. GalA data fitted a second order polynomial function $\left(R^{2}=0.837\right)$ as follows (Eq. (3)):

$$
\begin{aligned}
& \text { GalA }=491.342+40.985 X_{1}+19.346 X_{2}+52.269 X_{3}-0.124 X_{1}^{2} \\
& +22.116 X_{2}^{2}+56.041 X_{3}^{2}+0.106 X_{1} X_{2}+34.886 X_{1} X_{3} \\
& \quad+39.819 X_{2} X_{3}
\end{aligned}
$$

Multiple regression coefficients are shown in Table 5. From the results in Table 5, only the quadratic coefficient of extraction duration variable and interaction coefficient between temperature and extraction duration were not significant by F-test at $95 \%$ confidence level.

Table 4 shows the results obtained from the analysis of variance (ANOVA). The regression was significant at 95\% confidence level by the F-test. The coefficient of determination, $\mathrm{R}^{2}$, for GalA content was 0.837 .

Fig. 2B demonstrates the effect of $\mathrm{pH}$ and temperature on galacturonic acid content. The lowest content was obtained when pectin was extracted at temperatures ranging from 68 to $94^{\circ} \mathrm{C}$ and at $\mathrm{pH}$ 2-1.5. By decreasing $\mathrm{pH}$ below 1.5 and/or increasing temperature, the galacturonic acid content was found to increase. The effect of
Table 5

Coded regression coefficients and statistical parameters obtained for the model built for galacturonic acid content of pectin extracted from pomegranate peel.

\begin{tabular}{lllll}
\hline Coefficient & Coefficient value & Standard deviation & $\mathrm{t}$ & P-value \\
\hline b0 & 491.342 & 0.984 & 499.55 & $<0.01^{* * *}$ \\
b1 & 40.985 & 0.653 & 62.80 & $<0.01^{* * *}$ \\
b2 & 19.346 & 0.653 & 29.65 & $<0.01^{* * *}$ \\
b3 & 52.269 & 0.653 & 80.10 & $<0.01^{* * *}$ \\
b11 & -0.124 & 0.653 & -0.19 & 85.3 \\
b22 & 22.116 & 0.653 & 34.81 & $<0.01^{* * *}$ \\
b33 & 56.041 & 0.653 & 88.22 & $<0.01^{* * *}$ \\
b12 & 0.106 & 0.853 & 0.12 & 90.6 \\
b13 & 34.886 & 0.853 & 40.92 & $<0.01^{* * *}$ \\
b23 & 39.819 & 0.853 & 46.70 & $<0.01^{* * *}$ \\
\hline
\end{tabular}

b0, bj, bjk and bjj, the estimated model coefficients; degree of freedom $=5$.

*** Significant at the level $99.9 \%$.

extraction duration over the galacturonic acid is given in Fig. 2A and $\mathrm{C}$. At low $\mathrm{pH}$ and for all temperatures, an increase of duration induced an increase of GalA content. This effect was marked for $\mathrm{pH}$ below $1.78(-0.5)$. The harsher conditions (acidic $\mathrm{pH}$, longer duration, higher temperature) all contributed to higher GalA content in the extracted pectins. As observed above, this could be linked to increased degradation of neutral sugar side-chains during pectin extraction.

Uronic acid contents of A8, A12 and A14 were above the $65 \%$ required to be considered pectin according to the FAO (UN Food and Agriculture Organization) and EU (European Union) [24]. This result demonstrated that pectin extraction from pomegranate peel was effective using severe conditions (Extraction duration: 65-100 min; Temperature $\geq 82^{\circ} \mathrm{C}$ and $\mathrm{pH}$ : 1-1.6).

\subsubsection{Neutral sugars}

The total content of neutral sugars varies with the source, the extraction conditions and the subsequent treatments [24]. High glucose contents were obtained systematically, while the main other sugars were galactose $(28-36 \mathrm{mg} / \mathrm{g}$ ) and arabinose $(2-50 \mathrm{mg} / \mathrm{g}$ ) (Table 2$)$. The origin of the glucose was not clear: residual starch, hemicelluloses notably xyloglucans, or sugar might be present in the pomegranate peels.

Except rhamnose, which is included in the pectin's structure, other neutral sugars, such as fucose, xylose and mannose were present, but in low amounts and were therefore assumed to be "contaminants" from hemicellulosic and sugar materials. The total neutral sugar content calculated as the sum of the individual neutral sugars ranged from 161 to $326 \mathrm{mg} / \mathrm{g}$.

All the extracts were rich in neutral sugars in comparison with those of sugar beet pulp pectin reported in various studies $(68-329 \mathrm{mg} / \mathrm{g})$ [9]; $(288 \mathrm{mg} / \mathrm{g})$ [25]; $(186 \mathrm{mg} / \mathrm{g})$ [26], which is already known for its high neutral sugar content relative to apple or citrus pectins [27].

Generally, use of more severe conditions led to lower amounts of total neutral sugars ( $161 \mathrm{mg} / \mathrm{g}$ versus $285,324,326,285$ for A8 versus $A 1, A 2, A 3, A 5$ respectively).

\begin{tabular}{|c|c|c|c|c|c|c|c|}
\hline Source of variation & & Sum of squares & $\begin{array}{l}\text { Degrees of } \\
\text { freedom }\end{array}$ & Mean square & Ratio & Significance & $\mathrm{R}^{2}$ \\
\hline \multirow[t]{2}{*}{ Regression } & Pectin yield & $4.58 \mathrm{E}+0003$ & 9 & $5.09 E+0002$ & 49.7837 & $<0.01^{* * *}$ & 0.978 \\
\hline & GalA & $1.38 \mathrm{E}+0005$ & 9 & $1.53 \mathrm{E}+0004$ & 2632.4398 & $<0.01^{* * *}$ & 0.837 \\
\hline \multirow[t]{2}{*}{ Residuals } & Pectin yield & $1.02 \mathrm{E}+0002$ & 10 & $1.02 \mathrm{E}+0001$ & & & \\
\hline & GalA & $2.69 \mathrm{E}+0004$ & 10 & $2.69 E+0003$ & & & \\
\hline \multirow[t]{2}{*}{ Total } & Pectin yield & $4.68 \mathrm{E}+0003$ & 19 & & & & \\
\hline & GalA & $1.65 \mathrm{E}+0005$ & 19 & & & & \\
\hline
\end{tabular}

Table 4

Statistical parameters obtained from the ANOVA test performed for the model built for pectin yield and galacturonic acid content (GalA) from pomegranate peel.

\footnotetext{
${ }^{* * *}$ Significant at the level 99.9\%.
} 
Version définitive du manuscrit publiée dans / Final version of the manuscript published in :

International Journal of Biological Macromolecules (2016), Vol. 93, p. 186-194,

DOI: 10.1016/j.ijbiomac.2016.08.033 - Journal homepage : www.elsevier.com/locate/ijbiomac

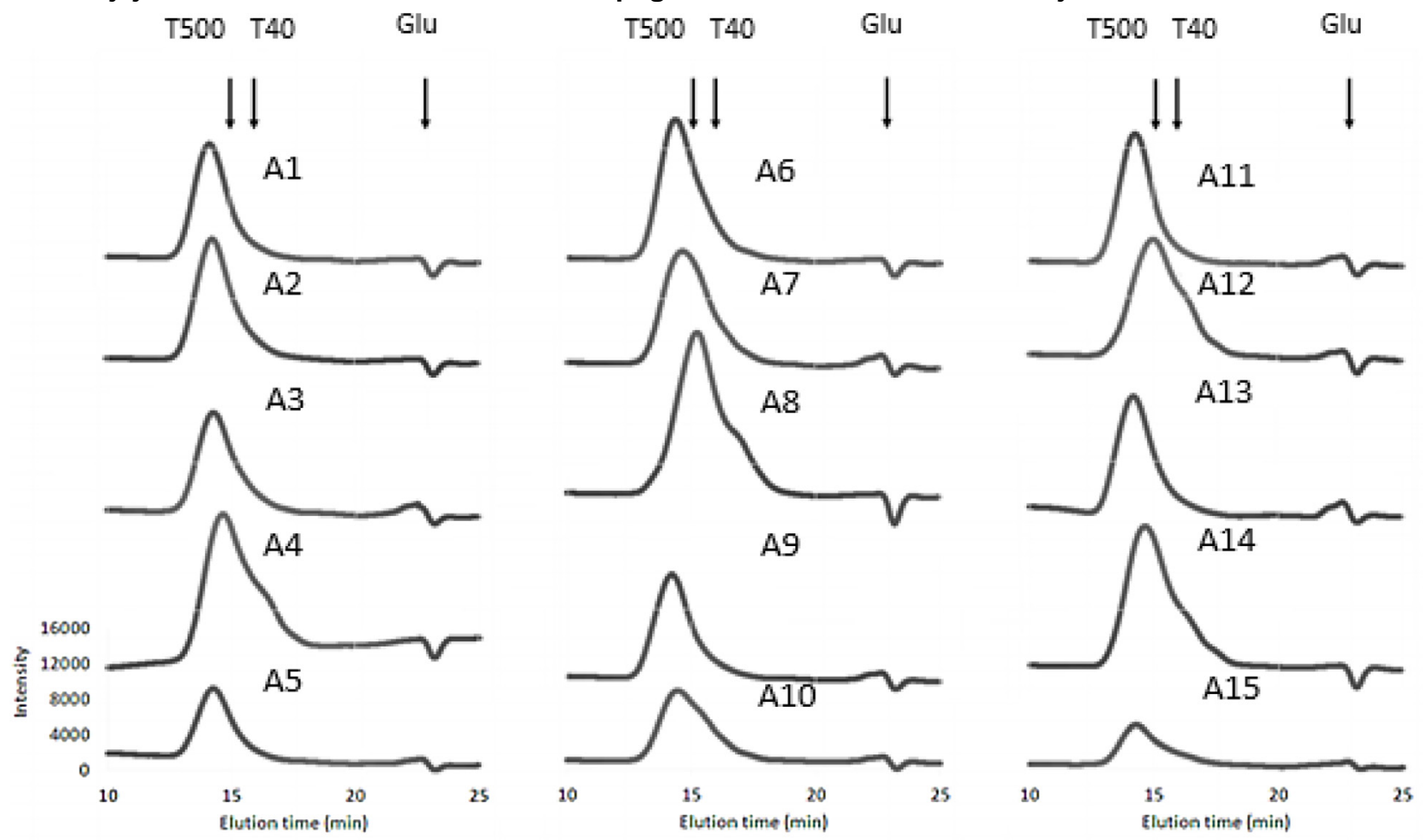

TSOO

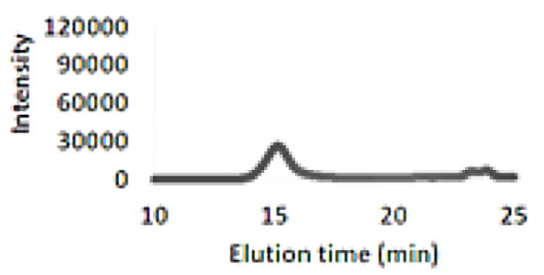

T40

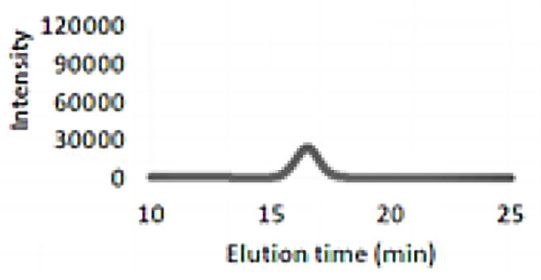

Glucose

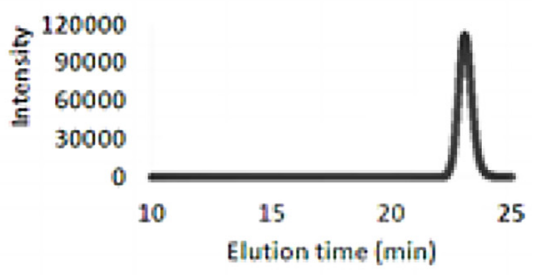

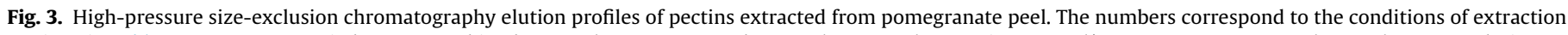

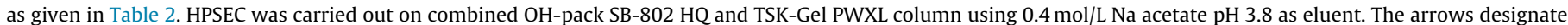
the elution times for dextrans T500 and T40. All samples were spiked with glucose.

Hence, under more extreme conditions the extraction of the rhamnogalacturonan backbone was enhanced while neutral sugar side-chains could be partially degraded. Specificity of extraction was also improved, with a relative decrease of the proportion of hemicellulose ballast in the extract.

On the other hand, the galactose content of most of the extracts was higher than that of arabinose which decreased with harsher extraction conditions (A8) suggesting either the predominance of arabinogalactan side chains and/or a higher degradation of arabinan side chains, probably due to the fact that arabinofuranosyl linkages are the most acid-labile [28].

The Gal A/Rha molar ratios ranging from 43 to 91 were high, though lower than those obtained for banana peels (210-402) [29] and for lemon by-product with acidified date juice (53-149) [30] (Table 2). This shows that the studied pectin samples contained probably a higher proportion of rhamnogalacturonic regions. This could be attributed to the $\mathrm{pH}$ values used for the pectin extraction ( $\mathrm{pH}$ 1-2.2 versus $\mathrm{pH} 3.4$ and 2.8 for pomegranate peel and lemon by-product, respectively).

Levigne et al. [31] reported that extraction at lower $\mathrm{pH}$ values led to higher amounts of pectins with more rhamnogalacturonan regions. Linkages between uronic acids or between uronic acids and rhamnose were reported as the most resistant, whereas arabinofuranosyl linkages are the most labile to acid hydrolysis [26].

\subsubsection{The hydrodynamic volume distribution}

In this work, the hydrodynamic volume distribution was determined by HPSEC [27] to compare the extracted samples. The elution times (ET) of the pectin samples and the partition coefficients (Kav) are listed in Table 2, and Fig. 3 shows the HPSEC profiles.

As shown in Fig. 3, temperature had a strong effect on the hydrodynamic volume distribution, in interaction with $\mathrm{pH}$. Samples extracted at $82^{\circ} \mathrm{C}$ with an extended extraction duration $(+1.68)$ (A10) or at the lowest $\mathrm{pH}(\mathrm{pH}=1)(+1.68)(\mathrm{A} 14)$ presented a profile of elution with a shift to the right, due to increased cleavage of pectins. This effect was not noted at $72{ }^{\circ} \mathrm{C}$ even though the $\mathrm{pH}$ and duration were fixed at their extreme values. The extraction at $92^{\circ} \mathrm{C}$ and $\mathrm{pH} 1.24(\mathrm{~A} 4, \mathrm{~A} 8)$ also resulted a cleavage of pectin. At the extreme temperature $\left(98.8^{\circ} \mathrm{C}\right)$ pectins were cleaved (A12) resulting in a low hydrodynamic volume.

The runs with the lowest elution times (A1, A9 and A13), indicating the highest hydrodynamic volumes, corresponded to pectin 
extracted at mild conditions. The lowest yield was obtained for A9. According to Scabio et al. [32], pectin with a less modified molecular mass profile can be obtained with extraction conditions giving low yields. In all trials, the mild extraction conditions were not always associated with high hydrodynamic volume, but severe conditions resulted in low hydrodynamic volumes (A8, A12, A14, A4 and A7). The longest elution time (ET=15.2 $\mathrm{min}$ ) with the highest partition coefficient (Kav of +0.008 ) which reflects the lowest hydrodynamic volume was detected in pectin extracted in the most severe conditions (A8). Whereas the lowest elution time (ET =14.1 $\mathrm{min}$ ) with the lowest partition coefficient (Kav of -0.134) was detected in pectin extracted in the mildest conditions (A1).

Pectin was probably partially degraded into smaller molecules during the extraction by the extreme extraction conditions. The decrease of the hydrodynamic volume could be attributed to the degradation of the side sugars chains and the hydrolysis of galacturonic acid chains.

\subsubsection{Degree of methylation}

Generally, pectin is characterised by its degree of methylation which is a major factor determining pectin functionality [27].

The pectin had a DM ranging between $30 \%$ and $55 \%$ (Table 2 ). The pectin was low methoxyl $(\mathrm{LM}, \mathrm{DM}<50)$ in all samples except $A 7$, A9 and centre point. The lowest DMs were obtained for the pectins extracted at the extreme extraction conditions (A8, A10, A12 and A14) probably because harsher conditions of temperature, duration and $\mathrm{pH}$ increased the de-esterification of polygalacturonic chain [33]. A negative correlation between yield and DM was observed in citric acid extracts from pomegranate peel [6]. In commercial applications, LM pectins are less common than high methoxyl (HM) pectins. However, in recent times, there is more interest in the manufacturing of LM pectins due to their gelling characteristic that is suitable for the production of low-calorie and dietetic foods.

\section{Conclusion}

Pomegranate peel has the potential to be a source of lowmethoxyl pectin which could be used as gelling agent in low-sugar jams for example. By using the response surface, the optimal conditions considering the yield were obtained graphically in order to reach the highest yield. The optimal conditions were $86^{\circ} \mathrm{C}, 80 \mathrm{~min}$ and $\mathrm{pH} 1.7$, respectively, providing a yield of $11.03 \%$. Degree of methylation, uronic acid and total neutral sugar contents as well as hydrodynamic volume were all markedly affected by the extraction conditions. Higher purities (estimated by the GalA content) but lower hydrodynamic volumes and degrees of methylation were obtained in harsher conditions. Further work needs to be carried out to investigate the gelation conditions of this naturally low methoxyl pectin.

\section{Acknowledgements}

The authors thank Mrs L. Touloumet for assistance with analytical methods. This work was financed by the Ministry of Higher Education and Scientific Research - Tunisia to Mouna Abid for an internship at UMR408.

\section{References}

[1] C. May, Industrial pectins: sources, production and applications, Carbohydr. Polym. 12 (1990) 79-99.

[2] D. Mohnen, Pectin structure and biosynthesis, Curr. Opin. Plant Biol. 11 (2008) 266-277.

[3] L. Qiu, G. Zhao, H. Wu, L. Jiang, X. Li, J. Liu, Investigation of combined effects of independent variables on extraction of pectin from banana peel using response surface methodology, Carbohydr. Polym. 80 (2010) 326-331.
[4] A. Miyamoto, K.C. Chang, Extraction and characterization of pectin from sunflower head residue, J. Food Sci. 5 (1992) 1439-1443.

[5] R.S. Faravash, F.Z. Ashtiani, The influence of acid volume, ethanol-to extract ratio and acid-washing time on the yield of pectic substances extraction from peach pomace, Food Hydrocolloids 22 (2008) 196-202.

[6] P.H. Pereira, T.I. Oliveira, M.F. Rosa, F.L. Cavalcante, G.K. Moates, N. Wellner, K.W. Waldron, H.M. Azeredo, Pectin extraction from pomegranate peels with citric acid, Int. J. Biol. Macromol. 88 (2016) 373-379.

[7] I.G. Moorthy, J.P. Maran, S. Muneeswari, S. Naganyashree, C.S. Shivamathi, Response surface optimization of ultrasound assisted extraction of pectin from pomegranate peel, Int. J. Biol. Macromol. 72 (2015) 1323-1328.

[8] M. Cam, Y. Hıșıl, Pressurised water extraction of polyphenols from pomegranate peels, Food Chem. 123 (2010) 878-885.

[9] B.M. Yapo, C. Robert, I. Etienne, B. Wathelet, M. Paquot, Effect of extraction conditions on the yield, purity and surface properties of sugar beet pulp pectin extracts, Food Chem. 100 (2007) 1356-1364.

[10] N. Danbaba, I. Nkama, M.H. Badau, M.N. Ukwungwu, A.T. Maji, M.E. Abo, H. Hauwawu, K.I. Fati, A.O. Oko, Optimization of rice parboiling process for optimum head rice yield: a response surface methodology (RSM) approach, IJAF 4 (2014) 154-165.

[11] D. Mathieu, J. Nony, R. Phan-Tan-Luu, NEMROD-Wsoftware, LPRAI, Marseille, 2000.

[12] H.N. Englyst, J.H. Cummings, Simplified method for the measurement of total non-starch polysaccharides by gas-liquid chromatography of constituent sugars as alditol acetates, Analyst 109 (1984) 937-942.

[13] N. Blumenkrantz, G. Asboe-Hansen, New method for quantitative determination of uronic acids, Anal. Biochem. 54 (1973) 848-849.

[14] C.M.G.C. Renard, C. Ginies, Comparison of the cell wall composition for flesh and skin from five different plums, Food Chem. 114 (2009) 1042-1049.

[15] G.E.P. Box, W.G. Hunter, J.S. Hunter, Statistics for Experimenters, an Introduction to Design, Data Analysis and Model Building, first ed., Wiley, New York, 1978.

[16] F. Kar, N. Arslan, Effect of temperature and concentration on viscosity of orange peel pectin solutions and intrinsic viscosity-molecular weight relationship, Carbohydr. Polym. 40 (1999) 277-284.

[17] K.C. Chang, N. Dhurandhar, X. You, A. Miyamoto, Sunflower head residue pectin extraction as affected by physical condition, J. Food Sci. 59 (1994) 1207-1210.

[18] Y. Nogata, K. Yoza, K. Kusumoto, H. Ohta, Changes in molecular weight and carbohydrate composition of cell wall polyuronide and hemicellulose during ripening in strawberry fruit, in: J. Visser, A.G.J. Voragen (Eds.), Pectins and Pectinases, Elsevier Science, Amsterdam, 1996, pp. 591-596.

[19] S.A. El-Nawawi, F.R. Shehata, Effect of the extraction temperature on the characteristics of pectin extracted from Egyptian orange peel, Biol. Wastes 24 (1988) 307-311.

[20] P.B. Mayers, G.L. Baker, Fruit jellies. VI the role of pectin. 2. The extraction of pectin from pectic materials, Del. Agr. Exp. Sta. Bull. 160 (1929) 1-64.

[21] W.C. Kim, D.Y. Lee, C.H. Lee, C.W. Kim, Optimization of narirutin extraction during washing step of the pectin production from citrus peels, J. Food Eng. 63 (2004) 191-197.

[22] Y. Chen, J.G. Zhang, H.J. Sun, Z.J. Wei, Pectin from Abelmoschus esculentus: optimization of extraction and rheological properties, Int. J. Biol. Macromol. 70 (2014) 498-505.

[23] H. Garna, N. Mabon, B. Wathelet, M. Paquot, New method for a two-step hydrolysis and chromatographic analysis of pectin neutral sugar chains, J. Agric. Food. Chem. 52 (2004) 4652-4659.

[24] A.G.J. Voragen, G.J. Coenen, R.P. Verhoef, H.A. Schols, Pectin, a versatile polysaccharide present in plant cell walls, J. Struct. Chem. 20 (2009) 263-275.

[25] H.C. Buchholt, T.M.I.E. Christensen, B. Fallesen, M.C. Ralet, J.F. Thibault, Preparation and properties of enzymatically and chemically modified sugar beet pectins, Carbohydr. Polym. 58 (2004) 149-161.

[26] J.F. Thibault, C.M.G.C. Renard, M.A.V. Axelos, P. Roger, M.J. Crépeau, Studies on the length of homogalacturonic regions in pectins by acid hydrolysis, Carbohydr. Res. 238 (1993) 271-286.

[27] A.G.J. Voragen, W. Pilnik, J.F. Thibault, M.A.V. Axelos, C.M.G.C. Renard, Pectins, in: A.M. Sephen (Ed.), Food Polysaccharides and Their Applications, Marcel Dekker Inc., NewYork, 1995, pp. 287-339.

[28] J.N. BeMiller, Acid-catalysed hydrolysis of glycosides, Adv. Carbohydr. Chem. Biochem. 22 (1967) 25-108.

[29] T.H. Emaga, S.N. Ronkart, C. Robert, B. Wathelet, M. Paquot, Characterisation of pectins extracted from banana peels (Musa AAA) under different conditions using different conditions using an experimental design, Food Chem. 108 (2008) 463-471.

[30] M. Masmoudi, S. Besbes, F. Abbes, C. Robert, M. Paquot, C. Blecker, H. Attia, Pectin extraction from lemon by-product with acidified date juice: effect of extraction conditions on chemical composition of pectins, Food Bioprocess. Technol. 5 (2012) 687-695.

[31] S. Levigne, M.C. Ralet, J.F. Thibault, Characterization of pectins extracted from fresh sugar beet under different conditions using an experimental design, Carbohydr. Polym. 49 (2002) 145-153.

[32] A. Scabio, H.C.R. Fertonani, M.H. Canteri-Schemin, C.L.O. Petkowicz, E.B.B. Carneiro, A. Nogueira, G. Wosiacki, A model for pectin extraction from apple pomace, Braz. J. Food Technol. 10 (2007) 259-265.

[33] A.J. Mort, F. Qui, N.O. Maness, Determination of the pattern of methyl esterification in pectin. Distribution of contiguous non esterified residues, Carbohydr. Res. 247 (1993) 21-35. 